\title{
Development of an engineering design process-based teaching and learning model for scientifically gifted students at the Science Education Institute for the Gifted in South Korea
}

\author{
Hwa-Jung Han and Kew-Cheol Shim *i)
}

\footnotetext{
* Correspondence: skcshim@kongju. ac.kr

Department of Biology Education, Kongju National University, Gongju, Republic of Korea
}

\begin{abstract}
This study suggests an engineering design process-based (EDP-based) teaching and learning model in science education and examines its educational potential for scientifically gifted students. This model consists of activities designed to help students come up with creative solutions using the engineering design process in a methodological manner to solve problems in everyday life. The EDP-based model has five stages: "defining the problem," "ingathering information," "generating the solution," "implementing the best solution," and "evaluating the solution and reflecting." The model was named DIGIER based on these five stages. This EDP-based model has functions for scientifically gifted education such as providing guidance for developing gifted education programs and helping educators use instructionally effective strategy for scientifically gifted students in the science education institute for the gifted, South Korea. Making a simple outdoor paper microscope program developed with the DIGIER model. The students recognize the old paper microscope dissatisfying and recognize a need to make a new simple outdoor paper microscope through experiment to observe stomata in plant leaves with an optical and old paper microscope. Then, the students create a new paper microscope design collaboratively. Therefore, DIGIER model can be a very effective teaching and learning strategy to increase the scientific creativity and collaborative abilities of scientifically gifted students that will play a pivotal role in the future society.
\end{abstract}

Keywords: Engineering design process, DIGIER model, Scientifically gifted student, Science education

\section{Introduction}

There are various educational approaches for the development of human resources in the science and technology field due to the accelerating development of science and technology. Every nation in the world is making considerable effort to develop engineering that can generate economic profit to improve the quality of life for humankind and increase their competitive edge in industry (Cho 2015; Kim et al. 2012b). One of these has been focused on the scientifically gifted education. Scientifically gifted

(c) The Author(s). 2019 Open Access This article is distributed under the terms of the Creative Commons Attribution 4.0 International License (http://creativecommons.org/licenses/by/4.0/), which permits unrestricted use, distribution, and reproduction in any medium, provided you give appropriate credit to the original author(s) and the source, provide a link to the Creative Commons license, and indicate if changes were made. 
students generally have above average science knowledge, scientific inquiry abilities, and creativity (Cho and Paik 2006) and show strong task commitment, interest, and motivation in science field (Jang et al. 2013; Shim et al. 2004). They have potential to choose future career courses related to science and technology and contribute to the development of science fields (Shim et al. 2003). Educational programs for gifted and talented students employ a variety of approached, and various studies demonstrated the effectiveness of pull-out programs, specialized classes, and other special programs. There are various educational approaches for gifted students who have interests and talents that allow for high achievement in a specific domain (Sahin 2015). Additionally, schools and curriculum services have focused on raising student achievement (Lee et al. 2012a; Sahin 2015).

In South Korea, the gifted education has been started on science high schools from 1980s. Scientifically gifted education has expanded with the enactment of the Gifted Education Promotion Act (Lee et al. 2012b; Lee et al. 2016b) through the science education institute or center for the gifted attached to universities or provincial education offices, which are designated and supported financially by the government. The trend of scientifically gifted education has been science-based approaches in the science education institute or center. Since the 2000s, STEM or STEAM-based educational approaches have increased, recently there has been a need for engineering design process-based education for scientifically gifted students.

The STEM or STEAM-based approach is being utilized as a new educational strategy in science education. STEM education is provided in the United States, United Kingdom, Australia, Finland, Germany, and Israel (Kim et al. 2012a). In South Korea, STEAM education is provided under the leadership of the Ministry of Education and the Korea Foundation for the Advancement of Science and Creativity. Sanders (2009) defined STEM education as education that integrates science, technology, engineering, and math in its content and methods and uses the engineering design process, which is a problem-solving process in technology and engineering, in a methodological manner, emphasizing its use as a teaching and learning strategy. A good example of incorporating the engineering design process into science education as a teaching and learning strategy can be found in the Next Generation Science Standards in the United States (NGSS Lead States 2013). The Next Generation Science Standards (NGSS Lead States 2013) integrate science and engineering into science education, emphasizing interdisciplinary connection and engineering design. They also highlight engineering design as a practice performed by engineers to design a model or system and as a core idea. In South Korea, the STEAM-based program for scientifically gifted students is currently applied through the general curriculum and is not suitable for the characteristics and levels of gifted students who already have high scientific interest. Therefore, it is necessary to develop more sophisticated STEAM programs for gifted students and to improve the educational environment for vitalizing STEAM education (Lee et al. 2012a).

Meanwhile engineering is a field of study that involves designing and developing products and processes useful for humankind by making use of knowledge across various fields including math and technology based on scientific knowledge (Kim et al. 2013a; Kim and Kim 2014; Moon 2008; NGSS Lead States 2013). Engineers design a product or process to meet human needs (National Research Council [NRC] 1996). Engineering design is the core of engineering (Koen 2003) and is one of common methods used by engineers to 
solve engineering problems. Through engineering design, engineers choose the best way to make a device and process that serve a particular purpose (National Academy of Engineering and National Research Council [NAE and NRC] 2009). Despite the growing importance of engineering over time, however, colleges, universities, and higher education institutions usually provide students with opportunities to do engineering design through engineering education. It has been argued that engineering education should also be provided at the elementary and secondary education level (Kim et al. 2013a; Sohn 2007). Every nation in the world has made diverse attempts at providing elementary and secondary school students with chances to experience engineering design and some have even tried a new educational approach involving introducing engineering design in science education rather than as a separate subject (Ministry of Education and Science Technology [MOEST] 2011; NRC 2012). In fact, engineering professionals consider science to be a subject capable of integrating with engineering education effectively in elementary and secondary education (Kim et al. 2013a), and in-service teachers believe that it would be better for engineering education content to be connected to science subjects when it appears in the regular curriculum (Kim et al. 2013b).

Engineering design is an option for a new educational strategy. The incorporation of engineering design into science education can help increase students' interest, positive attitude, and understanding with regard to occupations in natural sciences and engineering (Hirsch et al. 2003; Jung 2012). This is because engineering design requires cooperation and active communication among the members to ensure the production of new and innovative products and solve engineering problems (Kang 2009; Lim et al. 2012) and is effective for improving the creativity and collaborative abilities of students (Baek et al. 2006; Jung 2012; Kang and Nam 2017). In addition, engineering design promotes the integration and application of such information to make use of scientific, mathematical, and technological knowledge in the problem-solving process and find an answer (Burghardt and Hacker 2004; Kwon and Park 2009). The application of engineering design for scientifically gifted students has resulted in the development of their creativity and the improvement of their collaborative abilities (Lee et al. 2016a). Moreover, it has increased their interest in science and engineering and enhanced their creative problem-solving abilities (Kang and Nam 2017). The engineering design can be a new effective teaching and learning strategy to cultivate scientifically gifted students' creativity and collaborative abilities and help give them a better perception of jobs in natural sciences and engineering (Apedoe et al. 2008; Ellefson et al. 2008; Kang and Nam 2017; Kolodner et al. 2003; Lee et al. 2013; Mehalik et al. 2008).

Current engineering design process-based science education programs, however, have been organized to provide simple experience in engineering design activities based on a few activities performed in engineering design. In addition, most of the programs developed to provide experience with the attributes of the engineering design process have been inclined toward technology subjects (Heo 2014; Kim and Kim 2014). There has been a shortage of science education programs developed based on engineering design processes for scientifically gifted students. The educational programs related to the engineering design process in South Korea have not considered the characteristics of the engineering design process. Additionally, the programs developed to experience the nature of the engineering design process are usually focused on the technology curriculum (Heo 2014; Kim and Kim 2014; Lee 2015). Therefore, there is a lack of science 
education programs that enable scientifically gifted students to experience the attributes of the engineering design process. Consequently, It is necessary to offer them opportunities to experience various job possibilities in natural sciences and engineering naturally.

To develop the programs for gifted education by considering the characteristics of scientifically gifted students, it is necessary to develop an appropriate educational model so that their characteristics can be developed and they be led toward natural sciences and engineering through talent cultivation (Noh and Choi 2017; Shim and Kim 2005; Shim et al. 2001). Thus, there is a need for engineering design process-based teaching and learning models for scientifically gifted students. This study set out to examine the characteristics and processes of engineering design through its literature study and used these results to develop an engineering design process-based teaching and learning model using the engineering design process.

\section{The engineering design process}

\section{Understanding of the engineering design}

Atman et al. (2007) saw engineering design as one of the important elements in engineering education and regarded it as one of the abilities that students needed to acquire. Dym et al. (2005) defined engineering design as a systematic and intellectual process of specifying the concepts of products, systems, and processes to meet the objectives of clients and the needs of users as well as restrictive conditions and the generation and evaluation of the specified concepts. Accreditation Board for Engineering and Technology(ABET 2017) defined engineering design as a repetitive decision-making process of changing resources in an optimized manner by applying basic scientific, mathematical, and engineering knowledge to achieve a goal in the process of devising a system, component, and process to meet the requirements, design criteria, codes, and standards within the constraints of health, safety, economy, ethics, policy, sustainability, making ability, and productivity. Benavides (2011) defined engineering design as establishing and implementing a plan to meet human needs. Asunda and Hill (2017) defined engineering design as an original, iterative, and open process of devising and developing a component, system, and process.

In addition, Lewis (2005) defined engineering design as a creative effort made in an uncertain environment from known conditions to unknown ones. Roh (2014) defined engineering design as the creative activity of making a new device or system or improving the current one. Haik and Shahin (2011) defined engineering design as making a new product to generate profit and contribute to society. An innovative idea should be in place in the development of a new unprecedented product or partially improved one to solve a problem based on various human needs, and it should be turned into a product successfully (Roy 1993). When these aspects are taken into account, it is obvious that creativity is a must throughout engineering design (Haik and Shahin 2011; Howard et al. 2008), which is why engineering design is also called creative engineering design (Lee and Kim 2012).

The engineering design process has been presented in various forms by many different engineering education researchers (Budynas and Nisbett 2015; Cross 2000; Dieter and Schmidt 2013; Dym et al. 2013; Haik and Shahin 2011; Khandani 2005; Pahl and 
Beitz 1996), but they share similar detailed and distinct stages (Table 1). In most cases, the engineering design process is comprised of design activities that take into consideration all the information needed to define a problem clearly, generate ideas for its solution, and develop them into high quality ideas for a product.

The details of the engineering design process are as follows: The engineering design process begins with identifying customer needs. At the problem-defining stage, engineers make clear, unambiguous, and concrete statements of customer requirements to specify what they want, check whether the requirements are feasible in reality, and determine what function will be added to the product. Realistic feasibility is taken into account at the problem-defining stage along with customer requirements, because if the product the customer wishes is impossible to make with the current technology or budget or is expected to cause environmental pollution or other problems, such solutions will not be embodied in reality and hold no engineering value.

The engineering design process aims to prevent such a loss in advance (Dym et al. 2013; Khandani 2005; Wright 2001). It is thus necessary to take into consideration both realistic constraints and customer requirements at the problem-defining stage. Engineers then collect information related to the problem, come up with several design ideas to solve it, and assess whether the various design ideas meet the customer requirements and are feasible in reality, and select the best design idea (Dym et al. 2013). Engineers determine how to deploy and assemble each of the parts and which material to be used to translate their best design ideas into real products and then design an assembly diagram on a plan (Dym et al. 2013). They then make detailed decisions about the arrangement, number, and material of parts and make a detailed design drawing, which is used to make a real product that will test the idea before the product launched on the market. That is, a prototype is made based on the design idea and tested to see whether it operates according to the design idea and whether the design idea meets the customer requirements (Dym et al. 2013; Khandani 2005; Kwon 2014). A prototype is a form in which the design idea is embodied physically or visually and offers a chance to check whether there is a problem with the design, whether the user's needs and the engineers' goals are fully reflected, and whether the design idea can function correctly as a solution (Deininger et al. 2017). In other words, engineers need to conduct a final check to figure out whether there are any remaining design concerns by testing the prototype before production. Once it is confirmed that the prototype works correctly, they improve and supplement the design idea based on the test results and complete the final design idea. If the prototype does not work correctly, however, they will identify its cause and start to redesign by repeating the engineering design process. The final design idea is documented in a technical report and design drawing and delivered to the client through an oral presentation (Dym et al. 2013).

\section{Characteristics of problem solving, scientific inquiry and engineering design}

Engineering design was compared with problem solving and scientific inquiry to examine its characteristics clearly (Table 2). Problem solving is a mental process of finding the best answer under limited conditions in a new problematic situation (Woods 1987) and the cognitive process of reaching the target state from the current one (Chi and Glaser 1983; Frazer 1982; Mayer and Wittrock 2006; Singer et al. 2012). Scientists 


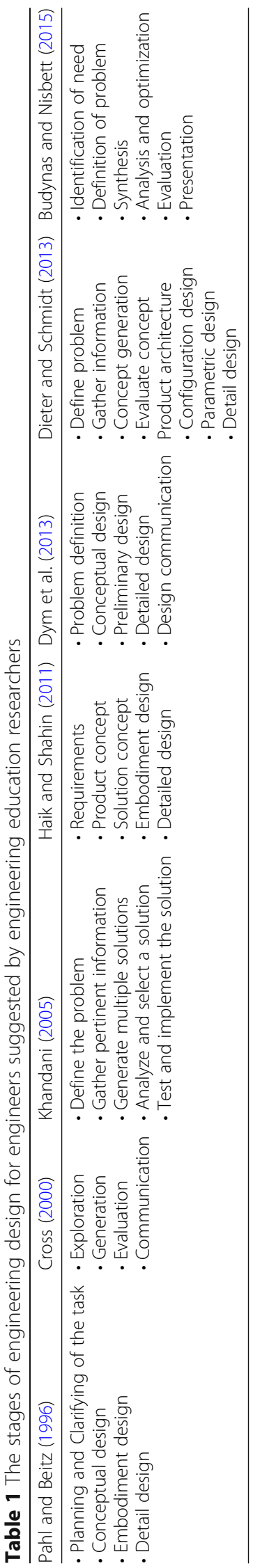


Table 2 Comparison of characteristics of problem solving, scientific inquiry, and engineering design

\begin{tabular}{|c|c|c|c|}
\hline & Problem solving & Scientific inquiry & Engineering design \\
\hline Meaning of problem & $\begin{array}{l}\text { Difference between } \\
\text { current and } \\
\text { desired situation }\end{array}$ & $\begin{array}{l}\text { Natural phenomena } \\
\text { that cannot be } \\
\text { explained by existing } \\
\text { scientific knowledge }\end{array}$ & $\begin{array}{l}\text { Developing products } \\
\text { and systems to meet } \\
\text { a specific need }\end{array}$ \\
\hline $\begin{array}{l}\text { Meaning of } \\
\text { problem solving }\end{array}$ & $\begin{array}{l}\text { Remove difference } \\
\text { between current and } \\
\text { desired situation }\end{array}$ & $\begin{array}{l}\text { Explaining the cause } \\
\text { of the natural } \\
\text { phenomenon }\end{array}$ & $\begin{array}{l}\text { Creating new products } \\
\text { and systems }\end{array}$ \\
\hline End product & Remedial action solution & New knowledge & New products and systems \\
\hline Stage & $\begin{array}{l}\text { Identify and select } \\
\text { the problem, analyze } \\
\text { the problem, generate } \\
\text { possible solutions, } \\
\text { select and plan the } \\
\text { solution, implement } \\
\text { the solution, evaluate } \\
\text { the solution }\end{array}$ & $\begin{array}{l}\text { Problem recognition, } \\
\text { formulate a hypothesis, } \\
\text { design inquiry, perform } \\
\text { inquiry, interpret inquiry, } \\
\text { formulate a conclusion, }\end{array}$ & $\begin{array}{l}\text { Define the problem, } \\
\text { gather pertinent information, } \\
\text { develop possible solutions, } \\
\text { select the best solution, } \\
\text { create prototype, test the } \\
\text { prototype, documentation } \\
\text { and presentation }\end{array}$ \\
\hline
\end{tabular}

conduct a scientific inquiry to generate new scientific knowledge based on the evidence collected through the research on the natural world (NRC 1996). A scientific inquiry is a process where scientists do research in order to understand the natural world (Chinn and Malhotra 2002; Hofstein and Lunetta 2004; NRC 1996) and search for the correct answer to their questions about nature (Meier et al. 1996). An engineering design is a process of making a creative product to meet the given constraints and user needs by taking advantage of the scientific, mathematical, and engineering knowledge of the designers.

Many scholars talk about scientific inquiry as a problem-solving process for scientists and engineering design as a problem-solving process for engineers. This explanation does not seem to fully address the goals of problem solving, scientific inquiry, and engineering design nor the characteristics of their processes. A problem-solving process involves coming up with various solutions and choosing the best one of them, similar to engineering design. While engineering design tests the functions of a prototype in order to determine whether the solution that seems best will solve the given problem, problem solving tests the resulting solution itself. In the generation of solutions, the given conditions should be taken into consideration both in problem solving and engineering design. In engineering design, one must take into account realistic conditions such as costs, materials, aesthetics, and marketability.

That is, science aims to generate new knowledge to understand the natural world, whereas engineering aims to fulfill human needs and demands by developing solutions to problems (Massachusetts Department of Education [MDE] 2006; Wulf 2002). While scientific inquiry begins by raising a question about a natural phenomenon, engineering design begins with human needs. The scientist then sets an answer to the question as a potential hypothesis in scientific inquiry, while the engineer defines the problem by taking into consideration the design criteria and constraints in engineering design (NRC 2012). While the final product of scientific inquiry by scientists is scientific knowledge, that of engineering design by engineers is an artifact such as a product or system (Burghardt 2013). As the final products of engineering design, artifacts can be common consumer goods or advanced products such as jets and missile systems 
(Daugherty 2009). Examples of scientific knowledge generated by scientific inquiry include "the sun rises in east and sets in west" and "fire generates heat." Those of engineering design include microwave ovens and the Golden Gate Bridge (MDE 2006). While scientific inquiry aims to find special and accurate knowledge to answer a question, engineering design aims to find the best or optimal solution by taking into account various factors including costs, materials, aesthetics, and marketability rather than finding a special or accurate solution (Burghardt and Hacker 2009).

Different engineers have different perceptions of an engineering design problem according to their different knowledge and experience (Lawson 2006). In engineering design, engineers devise different and diverse solutions from one another and regard their solutions as temporary right answers. Since there is no turning all of these diverse solutions into reality, they have to select the best solution. The choice of the best solution can vary according to who solves the situation or problem and which value is held strong by the person trying to solve the problem, which means that engineers need to consider different solutions and choose the most appropriate one (Burghardt and Hacker 2009).

Unlike the process of scientific inquiry, research problem solving, the engineering design process's products are made based on the solutions devised by engineers that are sold in the market, which means that the solutions should be assessed to see whether they can solve problems. A prototype is thus made to check by eye, and its functions are evaluated. If a prototype does not work correctly, another prototype will be made based on a different solution and evaluated for its functions. Another approach is to revise the best solution based on feedback after the prototype test and repeat the process of making a prototype and evaluating its functions. The engineering design process will be repeated over and over again until the best solution is confirmed (Budynas and Nisbett 2015; Dym et al. 2013; Pahl and Beitz 1996).

In the engineering design process, information collected to devise various solutions offers details about the physical standards and costs of materials for the product to be made and can assist with deciding on a manufacturing method (Bursic and Atman 1997). It also offers information about matters that restrict the solution and design criteria (Ennis and Gyeszly 1991) and assistance to setting safety and legal accountability (Bursic and Atman 1997). The characteristics of engineering design involve designing a solution to a problem, but the design stage should consider and meet the requirements of size, weight, reliability, stability, economic factors, impact on the environment, and manufacturing feasibility (Wulf 2002). The goal of engineering design is to make a product that will meet the market needs, and it is oriented toward the application of a solution in reality. Engineering design should thus consider the economy, ethics, and legal accountability.

\section{Characteristics of engineering design process}

In South Korea, the 2015 Revised Science Curriculum presented the core competencies that should be cultivated in science education, including scientific thinking, inquiry, problem solving, communication abilities, and scientific participation and lifelong study abilities (Ministry of Education [MOE] 2015). Schools should provide students with opportunities to experience the attributes of the inquiry process implemented by 
scientists in science education so that the students can develop these core competencies. Some have argued that science education in school is currently not meeting these needs of the inquiry core competency (Park 2006; Shin and Kim 2009; Yang et al. 2008). Alternatives to inquiry have been developed, including models based on the engineering design process in science education.

The engineering design process-based teaching and learning models in science education examined in the previous literature (Guerra et al. 2012; Heo 2014; Hynes et al. 2011; Kim et al. 2013; MDE 2006) have been organized to show the systematic stages in developing various solutions to problems based on scientific and mathematical knowledge and turning them into creative products (Table 3). As the stage titles indicate, however, these models focus on improving the design abilities involved in making a product and problem-solving abilities, thus failing to give full consideration to scientific knowledge and inquiry due to the ambiguous goals of science education. It is critical to recognize a problem in a systematic manner and define it correctly in order to come up with a good solution (Lee and Ahn 2015), which requires a designer to have enough knowledge of the problem to define it accurately (Cho et al. 2008).

These engineering design process-based teaching and learning models in science education lack materials to specifically clarify the functions or forms of new products at the problem-defining stage. Problems that engineers try to solve in engineering design are real problems aimed at solving inconveniences in daily life. Previously developed engineering design process-based teaching and learning models in science education, however, present virtual problematic situations at the problem-defining stage and are organized for students to virtually solve the problem as if they were role-playing engineers, thus failing to fully reflect the attributes of the engineering design process whose aim is to solve a problem in real life.

Previous engineering design process-based teaching and learning models in science education have set redesign, which the repetition of the engineering design process, as a separate last stage, thus making the students consider only the restart of a new engineering design process as redesign. Redesign, however, can also involve identifying the causes of malfunctions in the prototype test and repeating some of the stages in the engineering design process. These characteristics of redesign can be found in the

Table 3 The stages of engineering design for students suggested by science education researchers

\begin{tabular}{|c|c|c|c|c|}
\hline MDE (2006) & Hynes et al. (2011) & Guerra et al. (2012) & Kim et al. (2013) & Heo (2014) \\
\hline $\begin{array}{l}\text { - Identify a need or } \\
\text { a problem } \\
\text { - Research the } \\
\text { need or problem } \\
\text { - Develop possible } \\
\text { solutions } \\
\text { - Select the best } \\
\text { possible solution } \\
\text { - Construct a } \\
\text { prototype } \\
\text { - Test and evaluate } \\
\text { the solution } \\
\text { - Communicate the } \\
\text { solution } \\
\text { - Redesign }\end{array}$ & $\begin{array}{l}\text { - Identify and } \\
\text { define problems } \\
\text { - Research the } \\
\text { need or problem } \\
\text { - Develop possible } \\
\text { solutions } \\
\text { - Select the best } \\
\text { possible solution } \\
\text { - Construct a } \\
\text { prototype } \\
\text { - Test and evaluate } \\
\text { the solution } \\
\text { - Communicate the } \\
\text { solution } \\
\text { - Redesign } \\
\text { - Complete }\end{array}$ & $\begin{array}{l}\text { - Identify the need } \\
\text { - Describe the need } \\
\text { - Characterize and } \\
\text { analyze the system } \\
\text { - Generate concepts } \\
\text { - Select concept } \\
\text { - Embody the } \\
\text { concept } \\
\text { - Test and evaluate } \\
\text { the concept } \\
\text { - Refine the concept } \\
\text { - Finalize and share } \\
\text { the design }\end{array}$ & $\begin{array}{l}\text { - Identify need and } \\
\text { problem } \\
\text { - Identify criteria } \\
\text { and constraint } \\
\text { - Develop possible } \\
\text { solutions } \\
\text { - Select the best } \\
\text { solution } \\
\text { - Create a model } \\
\text { - Test and evaluate } \\
\text { the solutions } \\
\text { - Communicate } \\
\text { the solution } \\
\text { - Redesign and } \\
\text { refine }\end{array}$ & $\begin{array}{l}\text { - Confirmation of } \\
\text { problems and } \\
\text { constraints } \\
\text { - Generate and select } \\
\text { the idea } \\
\text { - Research and } \\
\text { development } \\
\text { - Making } \\
\text { - Evaluation } \\
\text { - Presentation and } \\
\text { discussion } \\
\text { - Improvement of the } \\
\text { design }\end{array}$ \\
\hline
\end{tabular}


findings of a survey on the definition of redesign among middle school teachers (Hynes 2012). Hynes (2012) found that the teachers defined redesign in three ways: finding the causes of a malfunction in the prototype and making it again with the help of teachers, making a new prototype with different materials or parts for the improvement of the old one, and starting a new engineering design process based on a new requirement or need after time has passed since the completion of the entire engineering design process. Setting redesign as a separate last stage may cause the misunderstanding of its characteristics. These findings indicate that there are difficulties with using the previous engineering design process-based teaching and learning models in science education as teaching and learning strategies that are aimed at cultivating scientifically gifted students. In the next chapter, a new engineering design process-based teaching and learning model is proposed by taking into consideration the characteristics of scientifically gifted students and the attributes of engineering design.

\section{Development of an engineering design process-based teaching and learning model in science education}

Engineering design process-based (EDP-based) learning is a model that organizes learning around engineering design processes. The purpose of this study is to develop an engineering design process-based teaching and learning model for scientifically gifted students. To this end, this study put together research on engineering design process-based teaching and learning models developed in science education (Hynes et al. 2011; NGSS Lead States 2013; MDE 2006) and research on the engineering design process of engineers (Cross 2000; Dieter and Schmidt 2013; Haik and Shahin 2011; Khandani 2005; Pahl and Beitz 1996) to identify similar activities between them and reorganize them.

The resulting model for an engineering design process goes through the stages of defining the problem, exploring information related to the problem, proposing various solutions, evaluating various solutions, selecting the best solution, making a prototype, evaluating the prototype, and communication. Redesign was also identified as a common activity in different engineering design processes, but it was not set as a separate stage and was instead presented as a major activity that can involve a return from the stage of assessing the prototype to other stages since it would repeat each stage. Many different studies called the idea proposed to solve a problem a design idea or solution. The present study called one a "solution" since it had the potential to solve a problem.

Each of the stages of engineering design identified in previous studies was reorganized for science education through an expert review. The stage of evaluating various solutions and that of choosing the best solution are closely related to each other since the best solution is selected based on the evaluation results of many different solutions. They were integrated into the single stage of selecting the best solution. The stages of making and evaluating a prototype are aimed at finding the best solution that will solve the problem in the most satisfying manner. The best solution then becomes the final solution based on the results of the prototype evaluation. These stages were integrated into the single stage of evaluating the solutions. As a result, six stages were developed: defining the problem, ingathering information related to the problem, proposing various solutions, selecting the best solution, evaluating the solution, and communication. 
A pilot test of the model was performed for scientifically gifted students in the science education institute for the gifted attached to university. The EDP-based learning needs more than formal lesson times of school science. The science education institute for the gifted attached to universities of South Korea teaches the gifted students for a relatively long time on the weekends and vacations (Choi 2009). The EDP-based educational model has a potential to be applied to the science education institute for the gifted. However, most gifted students had difficulties in implementing the activities of each stage in the model as they were not accustomed to the engineering design process.

The scientifically gifted students recorded a very high participation rate in the activity of making a prototype at the stage of evaluating the solution and displayed low concentration and participation in the other stages. Thus, the stages and major activities of an engineering design process-based teaching and learning model were revised. The revised engineering design process-based teaching and learning model had five stages: defining the problem, ingathering information related to the problem, generating the solution, implementing the best solution, and evaluating the solution and reflecting. It is called as DIGIER model, which are the initials of the stages (Fig. 1).

The revision and supplementation of the stages and major activities of an engineering design process-based teaching and learning model led to the following: The stage of defining the problem was revised to contain more specific activities fit for the characteristics of this stage so that scientifically gifted students could make an easy approach to the definition of the problem. The stage of ingathering information related to the problem remained at the level of simple information search and was not very helpful with product making. This stage needs revision and supplementation with activities involving gathering information related to the problem and sorting out the gathered information based on its relation to the problem. Since the word proposing in the stage of proposing various solutions was not interpreted as coming up with creative solutions, the stage title was changed to generating the solution based on the nature of this stage. Also included in the stage of generating the solution was the selection of the best solution through the supplementation and revision of the old best solution based on the evaluation results of each group's best solution in texts or drawings on an activity sheet. The activity of making a prototype performed at the stage of evaluating the solution involved the actual making of the solution in the heads of the students, which was why a separate stage of implementing the best solution was created for the activity. The results of the preliminary study showed that redesign, which is returning to one of the previous stages when a problem is found with the functions of the prototype at the stage of evaluating the solution, would be difficult for students because a repeat of the

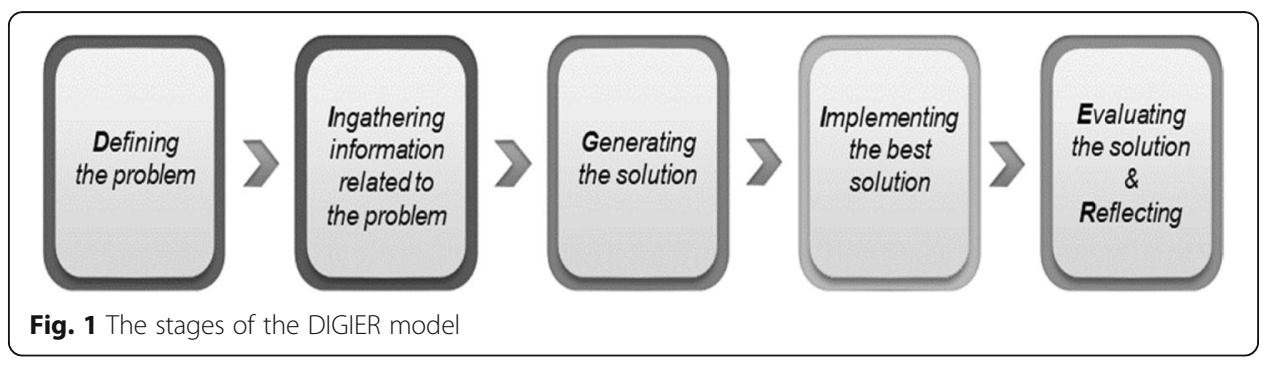


design process through redesign would exceed the time limitations at a center for gifted education. The redesign activity was therefore eliminated. At the stage of communication, students make a presentation on the characteristics of the prototypes they made in their groups and write and present a final report encompassing the entire design process. The results of the preliminary study, however, showed that scientifically gifted students were able to understand the design context only with the activity sheet they worked on during a lesson and were able to come up with ideas for a new solution after receiving feedback from other groups and their evaluation opinions in a presentation on the characteristics of each group's prototype. With the feedback activity taken into consideration, this stage was revised to evaluating the solution and reflecting.

The stages and activities of the DIGIER model are shown in Table 4. The defining the problem stage is the specific clarification of the problem to be solved. The students will recognize a problematic situation, set a design goal based on it, and define the problem clearly through its specific clarification. The gathering information stage is the collection of information related to the problem. The students will gather various pieces of information to solve the problem by taking advantage of diverse sources, check the information's relation to the problem in order to judge its usefulness, and select optimal pieces of information. The generating the solution stage involves coming up with creative solutions to solve the problem. At this stage, all the members of the groups will come up with various solutions for the problem and work together in presenting and evaluating their solutions. Based on the evaluation results, they will generate a feasible real-world solution in groups and elaborate and arrange their solutions to share them with others. The implementing the best solution stage is where the students make a prototype based on the group's solution and arrange its characteristics. The students will systematically check how to reflect their solutions onto real-world things and make a prototype. The final stage of evaluating the solution and reflecting is where the students assess whether the group's solution was implemented correctly and devise a new solution through feedback from other groups. All the group members will find

Table 4 Stages and activities of the DIGIER model

\begin{tabular}{ll}
\hline Stage & Activity \\
\hline Defining the problem & - Recognizing the problematic situation \\
- Recognizing the need for problem solving \\
- Specific clarification of the problem to be solved \\
- Gathering information related to the problem by \\
taking advantage of diverse sources \\
- Organizing information by checking the relations \\
between problem and information \\
- Generating various solutions \\
- Refining their solutions \\
- Making a presentation and evaluating by the group \\
- Generating a solution by the group based on \\
the evaluation results \\
- Elaborating the solution by the group \\
- Making a prototype based on the group's solution \\
- Arranging the prototype's characteristics \\
- Presenting and evaluating of the prototype's \\
characteristics by the group \\
- Finding improvement measures for the \\
implementing the best solution \\
- Generating a new solution
\end{tabular}


improvement measures for the prototype together through presentation and evaluation by the group, come up with ideas for a new product, and generate a new solution.

An example of educational programs developed with the DIGIER model for scientifically gifted in the science education institute for the gifted attached to university is shown in Table 5. The science education program's subject is to make a simple outdoor paper microscope. At the stage of defining the problem, the students conduct an experiment to observe stomata in plant leaves with an optical and paper microscope and sort out the advantages and disadvantages of a paper microscope. Through this experimental activity, the students find the old paper microscope dissatisfying and recognize a need to make a new simple outdoor paper microscope. Based on the information obtained from the activity, the students discuss what functions and forms would be needed for the group to make such a paper microscope and set a common design goal concerning the characteristics of the paper microscope they would like to make based on communication with the group members.

At the stage of ingathering information, the students follow the instructions on the activity sheet to search for and collect information about portable microscopes in the market with the search function on a smartphone. Then, the students organize the information, check the information's relation to the characteristics of the paper microscope to be developed, and select optimal pieces of information.

At the stage of generating the solution, the students come up with paper microscope designs individually based on the optimal information from the stage of ingathering information and convey their designs on the activity sheet with texts or drawings. Then,

Table 5 Stages and activities of making a simple outdoor paper microscope program for scientifically gifted students in the science education institute for the gifted

\begin{tabular}{|c|c|}
\hline Stage & Activity \\
\hline Defining the problem & $\begin{array}{l}\text { 1) Discussing the characteristics of plant leaves by observing the front and back } \\
\text { of a leaf in various plants with a loupe. } \\
\text { 2) Observing stomata in the front and back of a leaf and their characteristics with } \\
\text { an optical microscope and drawing what has been observed with an optical } \\
\text { microscope.. } \\
\text { 3) Observing stomata in the front and back of a leaf with a paper microscope and } \\
\text { drawing what has been observed with a paper microscope. } \\
\text { 4) Comparing the paper microscope used with an optical one and sorting out the } \\
\text { advantages and disadvantages of a paper microscope. } \\
\text { 5) Thinking of what should be improved in a paper microscope when it is used in } \\
\text { the outdoor field and sorting out the reasons for its improvement. }\end{array}$ \\
\hline Ingathering information & $\begin{array}{l}\text { Using the search function on a smartphone to examine what kinds of portable } \\
\text { microscopes are in the market. }\end{array}$ \\
\hline Generating the solution & $\begin{array}{l}\text { 1) Designing a more useful and simple outdoor paper microscope based on the } \\
\text { detailed drawing of a paper microscope. (Do a simple sketch.) } \\
\text { 2) Explaining your "simple outdoor paper microscope" designs and sorting out } \\
\text { their positive (P), negative }(\mathrm{M}) \text {, and interesting (I) points. } \\
\text { 3) Crating the best design for the simplest outdoor paper microscope based on } \\
\text { the various designs of the members through a group discussion. }\end{array}$ \\
\hline $\begin{array}{l}\text { Implementing the best } \\
\text { solution }\end{array}$ & $\begin{array}{l}\text { 1) Making a paper microscope based on the ideas of the group. Observing } \\
\text { stomata in the front and back of a leaf with the completed paper microscope } \\
\text { and drawing what has been observed. } \\
\text { 2) By comparing it with the old paper microscopes, freely discussing the } \\
\text { performance and characteristics of the new paper microscope that the group has } \\
\text { made with the members. }\end{array}$ \\
\hline $\begin{array}{l}\text { Evaluating the solution and } \\
\text { reflecting }\end{array}$ & $\begin{array}{l}\text { 1) Making a presentation on the paper microscope created by the group and } \\
\text { evaluating the ones made by the other groups together. } \\
\text { 2) By assimilating the contents of the group presentations, discussing the ways to } \\
\text { make a "simple outdoor paper microscope" in a simple manner. }\end{array}$ \\
\hline
\end{tabular}


the members of each group share their ideas in a group presentation, evaluate each other's paper microscope designs with the plus-minus-interesting (PMI) strategy regarding various aspects (including positive, negative, and interesting points), and examine whether their paper microscope designs would be logical and rational. Based on the evaluation results, the members of each group exchange ideas and generate a paper microscope design by the group. Each group conveys their specific paper microscope designs on the activity sheet with text or drawings. .

At the stage of implementing the best solution, the students make a paper microscope based on the group's designs and arrange the characteristics of their paper microscopes. At the stage of evaluating the solution and reflecting, the students make a presentation on the characteristics of the paper microscope made based on group's designs, share paper microscopes and their designs with one another, and make a new design based on feedback among the groups. At this stage, the students make a presentation on the characteristics of the paper microscope made by the group and assess to what extent the paper microscope fulfills its design goal in an experiment for observing stomata in leaves. During this process, the students find improvement measures for their paper microscope based on feedback from other groups. Based on the improvement measures, each group comes up with ideas for a new paper microscope, and generates a new paper microscope design.

\section{Conclusion and suggestions}

This EDP-based model has the potential to be effective in teaching scientifically gifted students in the gifted education field. The DIGIER model is comprised of five stages: defining a problem, ingathering information, generating the solution, implementing the best solution, and evaluating the solution and reflecting. The model was developed to increase the scientific creativity and collaborative abilities of scientifically gifted students for a considerable number hours, so it can be useful and effective for the science education institute for the gifted.

The DIGIER model was organized using the activities of the engineering design process as a methodology to make a creative solution to solve daily issues so that scientifically gifted students will be able to improve their scientific creativity and collaborative ability. The DIGIER model can help to increase fluency, flexibility, integrity, sophistication, and originality in the categories of scientific creativity and communicative skills, and cooperative ability and leadership in the category of collaborative ability. To teach scientifically gifted students effectively, educators need to develop a program based on the EDP-based model and an understanding of characteristics of the DIGEIR model. They need to try to provide an atmosphere for stimulating gifted students and encourage them to increase their interest in science and engineering and enhance their creative problem-solving abilities. These programs of the DIGIER model can show an example of effective teaching and learning approaches to cultivate scientifically gifted students' creativity and collaborative abilities and help have a positive influence on their career choices related to natural sciences and engineering.

On the other hand, the DIGIER model does not fully reflect the inclusion of redesign. More time will be needed to create the DIGIER ${ }^{2}$ model (Fig. 2), which will include redesign. Redesign can work in two ways: First, a product is completed once all the stages of an engineering design process-based teaching and learning model are covered, from 


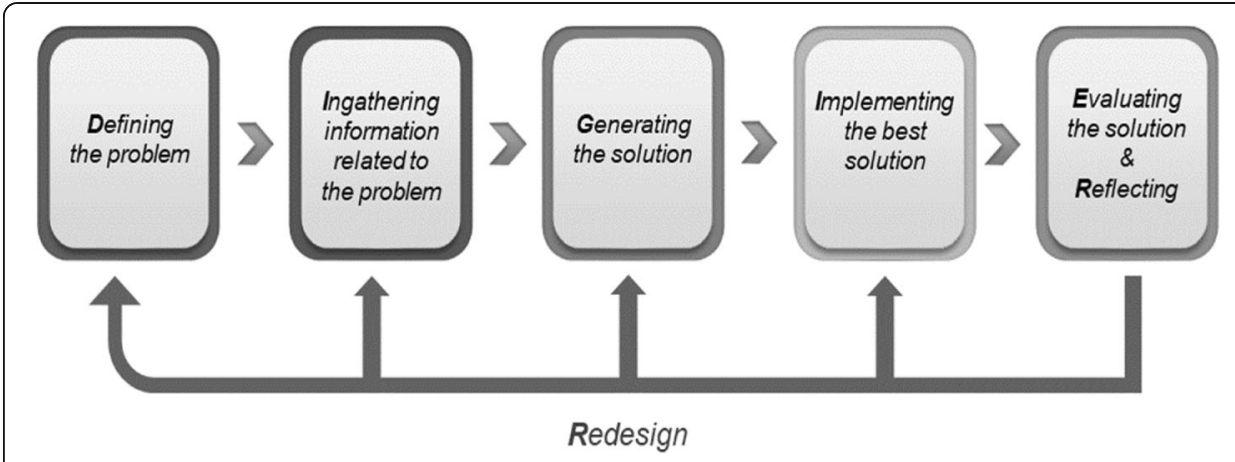

Fig. 2 Stages of the DIGIER² Model

the stage of defining the problem to the stage of evaluating the solution and reflecting. When there is a need to develop a new product due to complaints about the old one or problems found in it, engineers will have to return to the stage of defining the problem and start a new engineering design process-based teaching and learning model. Secondly, a problem might be found with the prototype after the stage of evaluating the solution and reflecting. In this case, reflective activities will follow to determine which of the stages contains a problem, including the definition of the given problem and the collection of information stages. Once the stage with a problem is identified, there is a need to return to it and engage in feedback activities. This process is repeated over and over again until the redesign process is completed. Redesign can be effective for helping students experience the attributes of the engineering design process at a more profound level and generate an innovative solution through the creative definition of a problem (Fig. 2).

\section{Abbreviations \\ ABET: Accreditation Board for Engineering and Technology; MDE: Massachusetts Department of Education; MOE: Ministry of Education; MOEST: Ministry of Education and Science Technology; NAE and NRC: National Academy of Engineering and National Research Council; NRC: National Research Council}

\section{Acknowledgements}

Not applicable

\section{Authors' contributions}

All authors contributed to the design of the research. $\mathrm{H}$-JH wrote the manuscript support from K-CS. All authors provided critical feedback and contributed to the final manuscript. Both authors read and approved the final manuscript.

\section{Authors' information}

Hwa-Jung Han holds a PhD in Biology Education and is a lecturer in the Department of Biology Education at Kongju National University in Kongju, South Korea. She holds a bachelor's degree, master's degrees, and doctoral degree in Biology Education from Kongju National University. Her research interests are in the areas of science education, and science education for gifted students.

Kew-Cheol Shim is a professor in the Department of Biology Education at Kongju National University in Kongju, South Korea. He holds holds a bachelor's degree, master's degrees, and doctoral degree in Biology Education from Seoul National University. He is interested in research and development of educational materials involved in science education, environmental education, scientifically gifted education and ecology.

\section{Funding}

Not applicable

Availability of data and materials

Data sharing not applicable to this article as no datasets were generated or analysed during the current study. 


\section{Consent for publication}

The authors agree that this article will be published in the APSE journal.

\section{Competing interests}

The authors declare that they have no competing interests.

Received: 23 June 2019 Accepted: 13 November 2019

Published online: 06 December 2019

\section{References}

Accreditation Board for Engineering and Technology. (2017). Criteria for accrediting engineering program. Retrieved from Accreditation Board for Engineering and Technology website: https://www.abet.org/wp-content/uploads/2018/02/E001-1 8-19-EAC-Criteria-11-29-17.pdf.

Apedoe, X. S., Reynolds, B., Ellefson, M. R., \& Schunn, C. D. (2008). Bringing engineering design into high school science classrooms: the heating/cooling unit. Journal of Science Education and Technology, 17(5), 454-465.

Asunda, P. A., \& Hill, R. B. (2017). Critical features of engineering design in technology education. Journal of STEM Teacher Education, 44(1), 25-48.

Atman, C. J., Adams, R. S., Cardella, M. E., Turns, J., Mosborg, S., \& Saleem, J. (2007). Engineering design processes: a comparison of students and expert practitioners. Journal of Engineering Education, 96(4), 359-379.

Baek, Y. S., Lee, J., Kim, E., Oh, K. J., Park, C., \& Chung, J. (2006). Achievements in the creativity education through freshmen engineering design. Journal of Engineering Education Research, 9(2), 1-16.

Benavides, E. M. (2011). Advanced engineering design: an integrated approach. Cambridge: Woodhead Publishing.

Budynas, R. G., \& Nisbett, J. K. (2015). Shigley's mechanical engineering design (10th ed.). New York: McGraw-Hill.

Burghardt, M. D. (2013). Interconnected STEM with engineering design pedagogy. Paper presented at 2013 ASEE Annual Conference, Atlanta, Georgia. Retrieved from https://peer.asee.org/19811.

Burghardt, M. D., \& Hacker, M. (2004). Informed design; a contemporary approach to design pedagogy as the core process in technology. The Technology Teacher, 64(1), 6-8.

Burghardt, M. D., \& Hacker, M. (2009). Perspectives on K-12 engineering. Retrieved from http://www.hofstra.edu/academics/ colleges/seas/ctl/ctl_k12engr.html.

Bursic, K. M., \& Atman, C. J. (1997). Information gathering: a critical step for quality in the design process. Quality Management Journal, 4(4), 60-75.

Chi, M. T., \& Glaser, R. (1983). Problem solving abilities. Pittsburgh: Learning Research \& Development Center.

Chinn, C. A., \& Malhotra, B. A. (2002). Epistemologically authentic inquiry in schools: a theoretical framework for evaluating inquiry tasks. Science Education, 86, 175-219.

Cho, E. B., \& Paik, S. H. (2006). A comparison analysis of intellectual characteristics between science-gifted education students and general students. Journal of the Korean Association for Science Education, 26(3), 307-316.

Cho, K. S. (2015). Case study on an engineering camp program involving engineering design activity and intra- and interteam work for high school students: plant factory as main theme. Journal of Engineering Education Research, 18(3), 46-58.

Cho, Y., Seong, J. S., \& Lee, H. (2008). Creativity education: developing creative problem-solving abilities. Seoul: Ewha Womans University Press.

Choi, H. (2009). A comparative analysis of educational programs of university-based gifted education center for the gifted in science. Journal of Science Education for the Gifted, 1(2), 1-16.

Cross, N. (2000). Engineering design method: strategies for product design (3rd ed.). Chichester: Wiley.

Daugherty, M. K. (2009). The "T" and "E" in STEM. In International Technology Education Association (Ed.), The overlooked STEM imperatives: technology and engineering K-12 education (pp. 18-25). VA: International Technology Education Association.

Deininger, M., Daly, S. R., Sienko, K. H., \& Lee, J. C. (2017). Novice designers' use of prototypes in engineering design. Design Studies, 51, 25-65.

Dieter, G., \& Schmidt, L. C. (2013). Engineering design (5th ed.). New York: McGraw-Hill Education.

Dym, C. L., Agogino, A. M., Eris, O., Frey, D. D., \& Leifer, L. J. (2005). Engineering design thinking, teaching, and learning. Journal of Engineering Education, 94(1), 103-120.

Dym, C. L., Little, P., \& Orwin, E. (2013). Engineering design: a project-based introduction (4th ed.). Hoboken: Wiley.

Ellefson, M. R., Brinker, R. A., Vernacchio, V. J., \& Schunn, C. D. (2008). Design-based learning for biology. Biochemistry and Molecular Biology Education, 36(4), 292-298.

Ennis, C. W., \& Gyeszly, S. W. (1991). Protocol analysis of the engineering systems design approach. Research in Engineering Design, 3(1), 15-22.

Frazer, M. J. (1982). Nyholm lecture. Solving chemical problems. Chemical Society Reviews, 11(2), 171-190.

Guerra, L., Allen, D. T., Crawford, R. H., \& Farmer, C. (2012). A unique approach to characterizing the engineering design process. Paper presented at ASEE Annual Conference \& Exposition, San Antonio, Texas. Retrieved from https://peer.asee. org/20878.

Haik, Y., \& Shahin, T. (2011). Engineering design process (2nd ed.). Stamford: Cengage Learning.

Heo, Y. U. (2014). Development of engineering design process and development of experience activity tasks with above process in unit for electrical/electronic engineering and information/communication engineering in engineering technology subject (Unpublished master's thesis, Korea National University of Education, Cheongju, South Korea). Retrieved from http://dcollection.knue.ac.kr/jsp/common/DcLoOrgPer.jsp?sltemld=000000026228.

Hirsch, L. S., Gibbons, S. J., Kimmel, H., Rockland, R., \& Bloom, J. (2003). High school students' attitudes to and knowledge about engineering. Paper presented at 33rd ASEE/IEEE Frontiers in Education Conference, Boulder, Colorado. Retrieved from https:/iieeexplore.ieee.org/stamp/stamp.jsp?arnumber=1264689.

Hofstein, A., \& Lunetta, V. N. (2004). The laboratory in science education: foundations for the twenty-first century. Science Education, 88(1), 28-54.

Howard, T. J., Culley, S. J., \& Dekoninck, E. (2008). Describing the creative design process by the integration of engineering design and cognitive psychology literature. Design Studies, 29(2), 160-180. 
Hynes, M. (2012). Middle-school teachers' understanding and teaching of the engineering design process: a look at subject matter and pedagogical content knowledge. International Journal of Technology and Design Education, 22(3), 345-360.

Hynes, M., Portsmore, M., Dare, E., Milto, E., Rogers, C., Hammer, D., \& Carberry, A. (2011). Infusing engineering design into high school STEM courses (report no. 165). Retrieved from the National Center for engineering and technology education website: http://ncete.org/flash/pdfs/Infusing\%20Engineering\%20Hynes.pdf.

Jang, J., Chung, Y., Choi, Y., \& Kim, S. W. (2013). Exploring the characteristics of science gifted students' task commitment. Journal of the Korean Association for Science Education, 33(1), 1-16.

Jung, J. H. (2012). A study on the effect and the development of a creative engineering technology-education program based on capstone design in elementary. Journal of Korean Practical Arts Education, 25(4), 195-215.

Kang, J. W., \& Nam, Y. (2017). The impact of engineering design-based STEM research experience on gifted students' creative engineering problem-solving propensity and attitudes toward engineering. Journal of the Korean Association for Science Education, 37(4), 719-730.

Kang, S. H. (2009). Factors related to creative achievement in engineering students. Journal of Engineering Education Research, 12(3), 59-72.

Khandani, S. (2005). Engineering design process. Retrieved from May 07, 2019 from http://saylor.org/site/wp-content/ uploads/2012/09/ME101-4.1-Engineering-Design-Process.pdf.

Kim, J. Y., Byeon, S. C., Lee, G. J., Lee, G. J., Shin, J. J., Park, H. J., \& Cho, H. S. (2012a). A study on K-12 STE(A)M policy for the creatively talented (research rep. RR 2012-043). Seoul: Korea Institute of Science and Technology Evaluation and Planning.

Kim, J. Y., \& Kim, K. S. (2014). The development of engineering design-based STEAM instructional material in middle school technology subjects. The Korean Journal of Technology Education, 14(2), 154-173.

Kim, Y. M., Huh, H. Y., Lee, C. H., \& Kim, K. S. (2013a). A study of engineering professionals' recognition about engineering education in primary and secondary school. Journal of the Korean Institute of Industrial Educators, 38(2), 136-155.

Kim, Y. M., Huh, H. Y., Lee, C. H., \& Kim, K. S. (2013b). Analysis of elementary and secondary school teachers' recognition about engineering education in elementary and secondary school. Journal of Engineering Education Research, 16(5), 9-17.

Kim, Y. M., Kim, H. J., Huh, H. Y., Lee, C. H., \& Kim, K. S. (2013). Development of an engineering education program in primary and secondary education: focus on construction engineering in middle school. The Korean Journal of Technology Education, 13(2), 21-41.

Kim, Y. M., Lee, C. H., \& Kim, K. S. (2012b). Objectives and contents of engineering technology subject education perceived by engineering professionals. The Korean Journal of Technology Education, 12(2), 221-249.

Koen, B. V. (2003). Discussion of the method: conducting the engineer's approach to problem solving. New York: Oxford University Press.

Kolodner, J. L., Gray, J., \& Fasse, B. B. (2003). Promoting transfer through case-based reasoning: rituals and practices in learning by design ${ }^{\text {TM }}$ classrooms. Cognitive Science Quarterly, 3, 183-232.

Kwon, H., \& Park, K. (2009). Engineering design: a facilitator for science, technology, engineering, and mathematics [STEM] education. Journal of Science Education, 33(2), 207-219.

Kwon, S. (2014). Teaching collaborative writing in engineering design courses. Journal of Engineering Education Research, $17(1), 26-41$.

Lawson, B. (2006). How designers think: the design process demystified. Oxford: Routledge.

Lee, D., Yoon, J., \& Kang, S. J. (2016a). The exploration on design thinking program's possibility as a strategy to foster group creativity of science-gifted students. School Science Journal, 10(2), 151-171.

Lee, E. S. (2015). Research trends and issues of engineering education in Korean elementary and secondary education. Journal of Engineering Education Research, 18(4), 45-56.

Lee, H., Park, K., Kwon, H., \& Seo, B. (2013). Development and implementation of engineering design and scientific inquirybased STEM education program. Korean Journal of Teacher Education, 29(3), 301-326.

Lee, J., Kang, B., \& Lee, D. (2016b). Law for gifted and talented education in South Korea: its development, issues, and prospects. Turkish Journal of Giftedness and Education, 6(1), 14-23.

Lee, J., Seo, Y., Jeong, Y., Kang, B., Lee, M., Park, J., Kim, A., Chae, H., Kang, Y., Seo, N., \& Ahn, J. (2012a). A study on the application of STEAM education for elementary and secondary students in 'gifted and talented classes' and 'gifted and talented centers'. (research rep. RR 2012-06). Seoul: Korea Education Development Institute.

Lee, K. S., \& Kim, K. (2012). A study on the education of creative engineering design methodology. Journal of Engineering Education Research, 15(4), 94-100

Lee, W. S., \& Ahn, T. W. (2015). A case study of an introduction to engineering design course based on problem solving. Paper presented at 2015 engineering education conference. Jeju, South Korea.

Lee, Y., Kim, Y., Lee, E., \& Kim, J. (2012b). The evaluation research on gifted education continuity. (research rep. RR 2011-06). Seoul: Korea Foundation for the Advancement of Science and Creativity.

Lewis, T. (2005). Coming to terms with engineering design as content. Journal of Technology Education, 16(2), 37-54.

Lim, C. I., Kim, Y. J., \& Kim, D. H. (2012). College of engineering students' perceptions of creativity education. Journal of Engineering Education Research, 15(2), 30-37.

Massachusetts Department of Education. (2006). Massachusetts science and technology/engineering curriculum framework. Malden: Massachusetts Department of Education.

Mayer, R. E., \& Wittrock, M. C. (2006). Problem solving. Handbook of Educational Psychology, 2, 287-303.

Mehalik, M. M., Doppelt, Y., \& Schunn, C. D. (2008). Middle-school science through design-based learning versus scripted inquiry: better overall science concept learning and equity gap reduction. Journal of Engineering Education, 97(1), 71-85.

Meier, S. L., Hovde, R. L., \& Meier, R. L. (1996). Problem solving: teachers' perceptions, content area models, and interdisciplinary connections. School Science and Mathematics, 96(5), 230-237.

Ministry of Education. (2015). Science curriculum. Sejong: Ministry of Education.

Ministry of Education and Science Technology. (2011). Science curriculum. Seoul: Ministry of Education and Science Technology.

Moon, D. Y. (2008). The development of pre-engineering educational program model based on STEM integration approach. Journal of Engineering Education Research, 11(2), 90-101. 
National Academy of Engineering and National Research Council. (2009). Engineering in K-12 education: understanding the status and improving the prospects. Washington, DC: National Academies Press.

National Research Council. (1996). National science education standards. Washington, DC: National Academies Press.

National Research Council. (2012). A framework for K-12 science education: practices, crosscutting concepts, and core ideas. Washington DC: National Academies Press.

NGSS Lead States. (2013). Next generation science standards: for states, by states. Washington DC: National Academies Press.

Noh, H., \& Choi, J. (2017). An analysis of the interpersonal competence of science-gifted students in school and sciencegifted education institutes. Journal of the Korean Association for Science Education, 37(2), 383-393.

Pahl, G., \& Beitz, W. (1996). Engineering design: a systematic approach (2nd ed.). (K. Wallace, L. Blessing \& F. Bauert, Trans.). London: Springer-Verlag (Original work published 1984).

Park, Y. S. (2006). Theoretical study on the opportunity of scientific argumentation for improvementing authentic scienctific inquiry. The Journal of the Korean Earth Science Society, 27(4), 401-415.

Roh, S. H. (2014). Creative ideas learning using the engineering design process. Seoul: Hanbit Academy.

Roy, R. (1993). Case studies of creativity in innovative product development. Design Studies, 14, 423-443.

Sahin, F. (2015). Educational programs, services and support for gifted students in Turkey. Journal of Theory and Practice in Education, 11(4), 1207-1223.

Sanders, M. (2009). Stem, stem education, stem mania. The Technology Teacher, 68(4), 20-26.

Shim, K. C., Kim, H. S., Kim, Y. S., \& Choi, S. Y. (2004). Study of learning style of science gifted/talented students in biology. Biology Education, 32(4), 267-275.

Shim, K. C., \& Kim, Y. S. (2005). Science gifted learning program: research and education model. Journal of the Korean Association for Science Education, 25(6), 635-641.

Shim, K. C., So, K. H., Kim, H. S., \& Chang, N. K. (2001). Study of interest in science of science gifted/talented middle school students 1: comparison between gifted/talented and general students. Journal of the Korean Association for Science Education, 21(1), 122-134.

Shim, K. C., So, K. H., Kim, H. S., \& Chang, N. K. (2003). Preference of science gifted/talented and general students for study course and occupation. Biology Education, 31(4), 292-298.

Shin, H., \& Kim, H. J. (2009). Development of inquiry-learning programs on surface growth visualizing the scientists' research process. New Physics: Sae Mulli, 58(5), 530-539.

Singer, S. R., Nielsen, N. R., \& Schweingruber, H. A. (Eds.). (2012). Discipline-based education research: understanding and improving learning in undergraduate science and engineering. Washington, DC: The National Academies Press.

Sohn, S. Y. (2007). K-12. Engineering Education, 14(4), 7-9.

Woods, D. R. (1987). How might I teach problem solving? New Directions for Teaching and Learning, 30, 55-71.

Wright, P. H. (2001). Introduction to engineering (3rd ed.). New York: Wiley.

Wulf, W. A. (2002). The urgency of engineering education reform. Journal of SMET Education, 3(3\&4), 3-9.

Yang, I. H., Kim, E. A., \& Oh, C. H. (2008). A case study of science high school students' hypothesizing and designing process. Secondary Education Research, 56(3), 293-331.

\section{Publisher's Note}

Springer Nature remains neutral with regard to jurisdictional claims in published maps and institutional affiliations.

\section{Submit your manuscript to a SpringerOpen ${ }^{\circ}$ journal and benefit from:}

- Convenient online submission

- Rigorous peer review

- Open access: articles freely available online

- High visibility within the field

- Retaining the copyright to your article

Submit your next manuscript at $\boldsymbol{s p r i n g e r o p e n . c o m ~}$ 